\title{
SOSIOLINGUISTIK: TEORI, PERAN, DAN FUNGSINYA TERHADAP KAJIAN BAHASA SASTRA
}

\author{
Abdurrahman \\ Dosen Jurusan Bahasa dan Sastra Arab, \\ Fakultas Humaniora dan Budaya, Universitas Islam Negeri (UIN) Malang. \\ Jalan Gajayana No. 50 Telepon (0341) 570872, Faksimile (0341) 570872 Malang 65144
}

\begin{abstract}
Sosiolinguistics is a study of language character, language variation, function of language, and language use in interaction and the language function in society. Language for a man of letters is a media to express ideas and present specific messages to society. These ideas come from intuition, imagination, and a man of letters personal experiences of in his society. The goal of sociolinguistics in language literature discussion is to give a description of the social condition of a society related to its language.
\end{abstract}

Key words

Sosiolinguistics, Language Literature, Man of Letters

\section{Pendahuluan}

Dalam kehidupan bermasyarakat seseorang tidak mungkin hidup menyendiri tanpa kehadiran orang lain atau tanpa bergaul dengan orang lain. Hal ini membuktikan bahwa pada hakekatnya manusia memang merupakan makhluk sosial. Manusia secara naluriah terdorong untuk bergaul dengan manusia lain, baik untuk menyatakan keberadaan dirinya, mengekspresikan kepentingannya, menyatakan 
pendapatnya, maupun untuk mempengaruhi orang lain demi kepentingan sendiri, kepentingan kelompok, kepentingan bersama. Berkenaan dengan hal tersebut bahasa memegang peranan yang sangat penting.

Bahasa merupakan alat untuk berkomunikasi, dalam arti luas. Joko Nurkamto (2001: 205) menjelaskan bahwa komunikasi merupakan sebuah proses transaksi dinamis yang memandatkan komunikator menyandi (to code) perilakunya, baik verbal maupun nonverbal, untuk menghasilkan pesan yang disampaikan melalui saluran tertentu dari komunikasi. Porter dan Samovar (1996) mensinyalir bahwa komunikasi akan lengkap apabila komunikasi yang dimaksud mempersepsi atau memahami perilaku yang disandi, memberi makna kepada perilaku itu, dan terpengaruh olehnya (dalam Joko Nurkamto, 2001: 205).

Memang dalam kenyataannya, bahwa keberadaan bahasa dalam kehidupan sosial tidak dapat dianggap sebagaimana dalam "ruang hampa". Bahasa dipakai sebagai wahana komunikasi manusia. Dalam hal ini Dwi Purnanto menjelaskan bahwa setidak-tidaknya harus memiliki dua ciri utama; (1) bahasa digunakan untuk mentransmisikan pesan dan (2) bahasa merupakan kode yang pemakaiannya ditentukan bersama oleh warga suatu kelompok atau suatu masyarakat (dalam MIBAS, 1999:92). Oleh karena itu, bahasa merupakan aspek gejala sosial dalam kehidupan manusia.

Mengingat bahasa merupakan gejala sosial, tentu saja faktorfaktor nonlinguistik atau faktor eksternal bahasa sangat berpengaruh terhadap pemakaian bahasanya. Faktor-faktor nonlinguistik tersebut misalnya faktor-faktor sosial, tingkat pendidikan, tingkat ekonomi, jenis kelamin, umur, dan sebagainya. Faktor-faktor nonlinguistik yang lain adalah faktor situasional, yaitu siapa yang berbicara, dengan bahasa apa pembicaraan itu diselenggarakan, kepada siapa, kapan, di mana, dan mengenai masalah apa pembicaraan itu. Adanya kedua faktor tersebut dalam pemakaian bahasa menyebabkan timbulnya variasi bahasa (Suwito, 1996:3-8).

Abdul Chaer dan Leonie Agustina (1995:81) mensinyalir bahwa 
dalam variasi bahasa atau ragam bahasa terdapat dua pandangan. Pertama, variasi atau ragam bahasa itu dilihat sebagai akibat adanya keragaman sosial penutur bahasa dan keragaman fungsi bahasa itu. Kedua, variasi atau ragam bahasa itu sudah ada untuk memenuhi fungsinya sebagai alat interaksi dalam kegiatan masyarakat yang beraneka ragam.

Variasi bahasa pada pemakaian bahasa tulis jenis fiksi (bahasa sastra) cenderung menggunakan ragam informal. Pemakaian ragam informal dapat mencerminkan suasana akrab, harmonis, dan santai, sehingga tujuan utama penulis untuk mempermudah pemahaman bagi pembaca dapat tercapai.

Dalam penulisan sebuah karya fiksi (novel) seorang sastrawan mempunyai kebebasan untuk menggunakan bahasa yang menyimpang dari kaidah yang berlaku selama tidak menimbulkan kesalahpahaman, karena karya sastra yang ditulis seorang sastrawan terkadang tidak bisa lepas dari kedwibahasaan sastrawan tersebut, bahkan seorang sastrawan pun dalam menggunakan bahasa sastranya sebagai media pencurahan ide kreatif juga banyak dipengaruhi oleh faktor sosiokultural yang melingkupi aktivitas kehidupannya. Faktor sosio-kultural itulah yang membuat bahasa sastra pengarang menjadi bernilai estetis.

Sastrawan adalah anggota suatu masyarakat bahasa tertentu. Sebagai anggota masyarakat bahasa tertentu seorang sastrawan dapat berperan ganda. peran pertama, ialah harus ikut serta memelihara, mengembangkan, dan melestarikan bahasa masyarakatnya. Peran kedua ialah peran yang tidak dimiliki oleh anggota masyarakat biasa, khususnya dalam hal menciptakan bentuk-bentuk baru dari bahasa yang dimiliki oleh suatu masyarakat. Bentuk-bentuk baru yang diciptakan sastrawan itu dapat berupa bentuk baru yang mengikuti kaidah bahasa, dapat juga menyalahi kaidah atau bahkan menyimpang sama sekali dari kaidah bahasa suatu masyarakat bahasa (Sugiarto, 1996:20).

Bahasa sastra dapat menjadi objek kajian bidang linguistik. Dalam hal ini yang dimaksudkan bukan membuat suatu kritik sastra, 
tetapi lebih bersifat mengkaji unsur kebenaran, unsur pemakaian bahasa dalam cipta sastra. Oleh karena itu, bahasa sastra dapat dikaji secara mikrolinguistik dan secara makroliguistik. Harimurti Kridalaksana (1985:91) telah mencoba memilah antara kajian bersifat makrolinguistik dengan kajian yang bersifat mikrolinguistik. Dari sisi makrolinguistik dapat dibuktikan atau dijelaskan bahwa suatu teori linguistik dapat menggunakan data bahasa sastra. Dari sisi makrolinguistik bahasa dapat dikaji secara interdisipliner dan secara terapan. Penelitian terhadap bahasa sastra secara makrolinguistik memperlakukan bahasa sastra sebagai data pemakaian bahasa. Adapun kajian bahasa sastra dari segi makrolinguistik yang bersifat interdisipliner berarti kajian bahasa yang memanfaatkan beberapa bidang kajian. Kajian bahasa sastra secara sosiolinguistik berarti kajiannya menggunakan teori sosiologi dan teori linguistik untuk segi kebahasaannya.

\section{Kajian Sosiolinguistik terhadap Bahasa Sastra}

Pertama, Sosiolinguistik. Sosiolinguistik mengkaji bahasa dengan memperhitungkan hubungan antara bahasa dengan masyarakat, khususnya masyarakat penutur bahasa itu. Jadi jelas sosiolinguistik mempertimbangkan keterkaitan dua hal, yakni linguistik untuk segi kebahasaan dan sosiologi untuk segi kemasyarakatannya.

Haugen mengemukakan, dalam makalahnya "Some Issues In Sociolinguistics" di sebuah buku yang berjudul Issues In Sociolinguistics, bahwa istilah sosiolinguistik pertama kali diperkenalkan oleh Haver C. Currie yaitu seorang guru besar (Profesor) di Universitas Houston, Texas 1952. Istilah ini kemudian dipublikasikan di Amerika oleh William Bright dan dipresentasikan dalam sebuah kongres Linguistik Internasional VIII di Cambridge 1962, kemudian dikembangkan lagi dalam sebuah Konferensi Internasional yang lebih formal di Los Angles, California 1962, dan menjadi populer hingga sekarang (Alwasilah, 1990:2-3).

Istilah sosiolinguistik yang menekankan tentang pengkajian bahasa dalam hubungannya dengan masyarakat, ada beberapa pakar 
yang mengemukakannya, Hymes (Alwasilah, 1990:2).mengemukakan bahwa, "the term sociolinguistics to the correlations between language and societies particular linguistics and social phenomena," artinya 'istilah sosiolinguistik untuk menghubungkan antara bahasa dan masyarakat serta bahasa dan fenomena dalam masyarakat'. Bahkan Chaklader Alwasilah (1990:2) sendiri mensinyalir bahwasanya, "sociolinguistics concertretes its study upon the societally patterned variation in languange usage" artinya 'sosiolinguistik menekankan pada pengkajian atas variasi pola-pola masyarakat dalam penggunaan bahasa'.

Hal senada juga diungkapkan oleh Hudson (1980:4) bahwa "sociolinguistics as the study of language in relation to society, inplying (intentionally) that sociolinguistics is part of the study of language" artinya 'sosiolinguistik sebagai pengkajian bahasa dalam hubungannya dengan masyarakat mengimplikasikan bahwa sosiolinguistik merupakan bagian dari ilmu bahasa'. Pendefinisian lain yang senada adalah pendapat Pride yaitu " sociolinguistics to study every aspect of use language that relates to its social and cultural functions" artinya 'sosiolinguistik itu untuk meneliti setiap aspek dari penggunaan bahasa yang berhubungan dengan fungsi sosial dan fungsi budaya' (Alwasilah, 1990:2). Suwito (1996:6) mengemukakan bahwa sosiolinguistik mempelajari bahasa dalam konteks sosio-kultural serta situasi pemakainya.

Dengan demikian dapat disimpulkan bahwa bahasa tidak saja dari sudut penturnya, tetapi juga dari sudut pendengarnya, karena pemakaian bahasa pada hakekatnya adalah proses interaksi verbal antara penutur dan pendenganrnya. Dalam proses interaksi, baik penutur maupun pendengar selalu mempertimbangkan kepada siapa ia berbicara, di mana, kapan, mengenai masalah apa, dan dalam situasi bagaimana, dan sebagainya, seperti yang telah dijelaskan oleh Fishman (1975:2). Hal yang serupa juga dikemukakan oleh Pateda (1987:3) bahwa yang dipersoalkan dalam sosiolinguistik antara lain: "who speak to speak (or write), what language (or what language variety), to whom, when, to what end". 
Hal-hal tersebut, menunjukkan bahwa sosiolinguistik memandang bahasa sebagai sistem sosial dan sistem komunikasi serta merupakan bagian dari masyarakat dan kebudayaan tertentu. Dengan demikian bahasa tidak saja dipandang sebagai gejala individual, tetapi juga merupakan gejala sosial. Di dalam masyarakat, seseorang tidak lagi dipandang sebagai individu yang terpisah dari yang lain. Ia merupakan anggota dari kelompok sosialnya. Hal ini menyebabkan bahasa dan pemakaian bahasa tidak diamati secara individual, tetapi selalu dihubungkan dengan kegiatannya dalam masyarakat (Suwito, 1996:2).

Dari uraian di atas dapat disimpulkan bahwa sosiolinguistik merupakan kajian yang bersifat interdisipliner yang mengkaji masalahmasalah kebahasaan dalam hubungannya dengan aspek-aspek sosial, situasional, dan budaya (culture). Oleh sebab itu apabila seseorang berbicara dengan orang lain di samping masalah kebahasaan itu sendiri, maka harus diperhatikan orang lain juga. Dengan memperhatikan sosiolinguistik, masalah ketidaktepatan pemakaian bahasa dalam konteks sosialnya dapat diminimalkan. Dengan memahami prinsipprinsip sosiolinguistik setiap penutur akan menyadari betapa pentingnya ketepatan pemilihan variasi bahasa sesuai dengan konteks sosial, di samping kebenaran secara struktural gramatikal.

Pada dasarnya sosiolinguistik dan linguistik mempunyai kesamaan metode penelitian, yang keduanya selalu didasarkan pada hasil yang dikumpulkan secara empiris dan ketat yang diterapkan pada sebuah data. Kesimpulan ditarik secara induktif dari hasil analisis data yang ketat pula. Meskipun keduanya mempunyai persamaan, keduanya juga mempunyai perbedaan-perbedaan yang cukup signifikan. Sosiolinguistik selalu memperhatikan konteks pemakaian bahasa (sastra) di dalam bentuk arti, perubahan bahasa, maupun pemerolehan bahasa. Sedangkan linguistik dalam analisisnya semata-mata menyoroti dari segi struktur bahasa sebagai kode.

Pada waktu orang akan berbicara, terlebih dahulu terbentuk suatu ide bahkan kesan di dalam kepala orang tersebut. Jika saatnya 
telah tiba, pesan itu disampaikan dalam bentuk ujaran yang kemudian didengar oleh orang yang diajak berbicara atau orang yang kebetulan hadir di dalam peristiwa bahasa tersebut. Dalam proses tutur ini pembicara selalu memperhitungkan faktor-faktor sosio-kultural dan sosio-situasional di samping faktor-fakror linguistik secara gramatikal.

Komponen tutur yang dianggap sebagai konteks sosial yang banyak dipengaruhi wujud wacana yang dituturkan oleh seseorang dalam suatu adegan tuturan oleh Dell Hymes dalam Poedjosoedarmo (1989: 4) disebut "Speech Component", bahkan lebih jauh Hymes menjelaskan bahwa terdapat enam belas komponen yang harus dikenali. Banyak komponen itu yang digabungkan menjadi satu karena mengandung redudancies dan tumpang tindih. Untuk mempermudah cara mengingat Hymes dalam Suwito (1992) mengusulkan formulasi Speaking dalam bahasa Inggris yang diambil huruf-huruf awalnya, yaitu sebagai berikut: (S): Setting dan Scene, yaitu tempat bicara dan suasana bicara (misalnya ruang diskusi dan suasana diskusi). (P): Partisipant, yaitu pembicara, lawan bicara dan pendengar, dalam diskusi adalah seluruh peserta diskusi. (E): End (purpose and goal), tujuan akhiar diskusi. (A): Act, yaitu suatu suatu peristiwa di mana seorang pembicara sedang mempergunakan kesempatan bicaranya. (K): Key (tone or spirit of act), yaitu nada suara dan ragam bahasa yang digunakan dalam menyampaikan pendapatnya, dan cara mengemukakan pendapatnya. (I): Instrumentalities, yaitu alat untuk menyampaikan pendapat, misalnya secara lisan, secara tertulis, lewat telepon dan lain sebagainya. (N): Norms (of interaction and interpretation), yaitu aturan permainan yang harus ditaati oleh setiap peserta diskusi. (G): Genres (bentuk dan ragam bahasa), yaitu jenis kegiatan diskusi yang mempunyai sifat-sifat lain dari jenis kegiatan yang lain.

Kedua, Bilingualisme (kedwibahasaan). Suatu masyarakat atau daerah yang memiliki atau memakai dua bahasa, maka masyarakat atau daerah itu disebut daerah atau masyarakat yang berdwibahasa atau bilingual. Orang yang dapat menggunakan dua bahasa disebut dwibahasawan atau orang yang bilingual (berdwibahasa) (Nababan, 
1993:27). Hal senada juga diungkapkan oleh Sinung Hartadi (2001:48) bahwa dalam masyarakat tutur yang terbuka tentu akan juga mengalami kontrak bahasa dengan segala fenomena kebahsaan sebagai akibatnya. Peristiwa kebahasaan yang mungkin terjadi sebagai akibat kontak bahasa itu antara lain disebut bilingualisme.

Ketika seseorang memakai dua bahasa dalam pergaulan dengan orang lain, dia berdwibahasa dalam arti dia melaksanakan kedwibahasaan yang disebut bilingualisme. Jadi bilingualisme adalah kebiasaan menggunakan dua bahasa dalam interaksi dengan orang lain. Jika berpikir tentang kesanggupan atau kemampuan seseorang berdwibahasa, yaitu memakai dua bahasa, kita disebut bilingualitas (dari bahasa Inggris "bilinguality"). Jadi orang yang "berdwibahasa" mencakup pengertian kebiasaan memakai dua bahasa, atau kemampuan memakai dua bahasa. Menurut Nababan (1993:27) membedakan "kedwibahasaan" (untuk kebiasaan) dan "kedwibahasawanan" (untuk kemampuan) dengan menggunakan istilah "bilingualisme" dan "bilingualitas." Selanjutnya bilingualitas merupakan suatu kemampuan seseorang menggunakan dua bahasa atau lebih.

Weinreich (1968:1) menjelaskan, "the practice of alternately using two languages will be called bilingualisme, and the person involved, bilingual" artinya "peristiwa pemakaian dua bahasa atau lebih secara bergantian oleh seseorang penutur disebut kedwibahasaan, dan orang yang berdwibahsaan disebut dwibahasawan'. Hubungan logika antara bilingualisme dan bilingualitas, adalah bahwa tidak semua yang mempunyai bilingualitas mempraktekkan bilingualisme dalam kehidupan sehari-hari, sebab ini tergantung pada situasi kebahasaan lingkungannya. Dapat saja orang yang tahu dua bahasa menggunakan satu bahasa selama dia di satu tempat atau keadaan (dalam waktu yang pendek atau lama), dan memakai bahasa yang kedua kalau dia berada di tempat atau keadaan yang lain (dalam waktu pendek atau lama). Bilingualisme seperti ini dilaksanakan secara berurutan yang dapat berjarak waktu yang lama.

Namun dapat juga kita mengerti bahwa tidak dapat seseorang 
mengerjakan bilingualisme tanpa dia mempunyai bilingualitas. Dengan kata lain mengerjakan bilingualisme berimplikasi pada bilingualitas: atau seorang harus mempunyai dahulu bilingualitas sebelum dia dapat mengerjakan bilingualisme (Nababan, 1993:28). Namun pengertian tentang kedwibahasaan selalu berkembang yang mempunyai kecenderungan meluas karena istilah kedwibahasaan bersifat nisbi atau relatif (Suwito, 1996:48). Pada mulanya kedwibahasaan selalu diartikan sebagai native control of two languages (mempunyai dua bahasa seperti menguasai bahasa ibunya) (Bloomfileld, 1968:56), kedwibahasaan yaitu jika kemapuan dalam kedua bahasa itu kira-kira sama maka itu disebut bilingualitas seimbang atau disebut oleh Halliday (1964) ambilingualism atau dalam peristilahan kita ambilingualitas (Nababan, 1993:33).

Pendapat lain tentang kedwibahasaan dijelaskan oleh Haugen dalam Suwito (1996:49), bahwa kedwibahasaan sebagai tahu dua bahasa (knowladge of two languages). Ini berarti bahwa dalam hal kedwibahsaan seorang dwibahasawan tidak harus menguasai secara aktif dua bahasa, tetapi cukuplah ia mengetahui secara pasif suatu bahasa oleh seorang penutur dapat ikut menciptakan kondisi kebahasaan yang menyimpang dari kaidah-kaidah yang sebenarnya kurang dikuasai. Hal itu dapat terjadi pada dwibahasawan.

Secara umum bilingualisme diartikan sebagai penggunaan dua bahasa oleh seorang penutur dalam pergaulannya dengan orang lain secara bergantian (Mackey, 1962:12) menurut Weinreich (1974:1) praktek penggunaan bahasa sebagai berikut:

"The practice of alternatively using two language will be called bilingualism, and the persons involed, Bilingual. Those instances of deviation from the norms of either language whith more than one language, i.e. as a result of language contact, will be refered to as interference phenomena".

'Praktek penggunaan dua bahasa secara bergantian disebut bilingualisme dan orang yang terlibat di dalamnya disebut bilingual. Sedangkan contoh penyimpangan dari norma-norma 
bahasa yang terjadi dalam ujaran para bilingual sebagai akibat dari familiaritas mereka dengan bahasa lebih dari satu, yaitu sebagai akibat kontak bahasa dikenal sebagai fenomena interferensi'.

Harimurti Kridalaksana (1985:26) membagi kedwibahasaan (bilingualisme) kedalam tiga kategori; Pertama, bilingualisme koordinat (coordinate bilingualism), dalam hal ini penggunaan bahasa dengan dua atau lebih sistem bahasa yang terpisah. Seseorang bilingual koordinat, ketika menggunakan satu bahasa, tidak menampakkan unsur-unsur dari bahasa lain. Pada waktu beralih ke bahasa yang lain tidak terjadi percampuran sistem. Kedua, Bilingualisme majemuk (compound bilingualism) di sini penutur bahasa menggunakan dua sistem atau lebih yang terpadu. Seorang bilingual majemuk sering "mengacaukan" unsur-unsur dari kedua bahasa yang dikuasainya. Ketiga, bilingualisme sub-ordinat (sub-ordinate bilingualism), fenomena ini terjadi pada seseorang atau masyarakat yang menggunakan dua sistem bahasa atau lebih secara terpisah. Seseorang yang bilingual sub-ordinat masih cenderung mencampuradukkan konsep-konsep bahasa pertama ke dalam bahasa kedua atau bahasa asing yang dipelajarinya.

Ketiga, Diglosia (diglossia). Selain kedwibahasaan, terdapat pula peristiwa yang menyangkut pemakaian dua bahasa atau lebih yang dipergunakan oleh seseorang atau sekelompok orang di dalam suatu masyarakat, yakni yang disebut dengan istilah diglosia. Robins (1992:497) menyatakan bahwa istilah diglosia mengacu kepada keadaan yang relatif stabil di mana sebuah bahasa atau salah satu ragam bahasa yang bergengsi tinggi tumbuh berdampingan dengan bahasa lain, masing-masing dengan fungsinya yang khusus dalam komunikasi.

Diglosia merupakan gejala sosial. Suatu masyarakat yang mempergunakan dua bahasa atau lebih sebagai alat komunikasi disebut masyarakat yang diglosik. Menurut Suwito (1996:61-62), di dalam masyarakat diglosik terdapat kecenderungan adanya penilaian terhadap bahasa yang "tinggi" dan bahasa yang "rendah". Pertama yang digunakan dalam situasi formal dan berkesan bermartabat, sedang yang 
kedua dipergunakan dalam situasi informal yang kurang bermartabat. Meski kelas pemilihan pemakaian antara keduanya, makin stabil situasi diglosik dalam masyarakat yang bersangkutan.

Istilah diglosia pertama kali dikemukakan oleh seorang guru besar bahasa Inggris di Texas, sekitar tahun 30-an. Kemudian pada tahun 1958 seorang sarjana Stanford C.A Fergusson mengutarakan ke dalam sebuah simposium. Fergusson dalam artikelnya yang berjudul "Diglossia" mendefinisikan diglosia sebagai berikut:

"Diglossia is a relatively stable language situation in which, in addition to the primary dialects of the language (which may include a standard or regional standards), there is very divergent highly condifeid (often gramatically more complex) superposed variety, the vehicle of a large and respected body of written literature, either of an earlier period or in another speech community, which is learned largely by formal education and is used for must written and formal spoken purposes but is not used by any sector of the community for ordinary conversation" (Hudson, 1980: 54).

'Diglosia adalah suatu situasi bahasa yang relatif stabil, di mana selain dari dialek-dialek utama satu bahasa (yang mungkin mencakup satu bahasa baku atau bahasa-bahasa baku regional), ada ragam bahasa yang sangat berbeda, sangat terkodifikasikan (sering secara gramatik lebih komplek) dan lebih tinggi, sebagai wahana dalam keseluruhan kesusastraan tertulis yang sangat luas dan dihormati, baik pada kurun waktu terdahulu maupun pada masyarakat ujaran lain, yang banyak dipelajari lewat pendidikan formal dan banyak dipergunakan dalam tujuan-tujuan oleh masyarakat apapun dalam pembicaraan-pembicaraan biasa' (Alwasilah, 1989:123).

Pemahaman Fergusson berawal dari fakta pembicara sering menggunakan lebih dari dari satu variasi bahasa dalam suatu suasana 
tertentu dan menggunakan variasi yang lain dalam kondisi yang lain pula. Dia juga mencatat bahwa terdapat kasus dua variasi bahasa hidup berdampingan dalam masyarakat, dengan masing-masing bahasa itu memiliki peranan tertentu. Kasus tersebut disebut diglosia.

Pengertian diglosia juga mempunyai kecenderungan meluas, seperti kata Fishman (1975:73), "Initally it was used in conection with a society that recognized two (or more) languages for into a societally communication." Artinya "pada hakekatnya adalah suatu yang dipergunakan untuk menyebut suatu masyarakat yang mengenal dua bahasa atau lebih untuk berkomuniksi di antara anggotanya'.

Dari uraian di atas terlihat bahwa diglosia tidak lagi terbatas pada pemakaian dua variasi dari satu bahasa di dalam suatu masyarakat seperti yang dikemukakan oleh Fergusson, tetapi termasuk juga pemakaian dua dialek atau dua logat dalam masyarakat yang sama. Jadi diglosia merupakan gejala sosial. Suatu masyarakat disebut diglosik apabila di dalam masyarakat itu dipergunakan dua bahasa atau lebih sebagai alat berkomunikasi yang masing-masing bahasa tersebut mempunyai fungsi yang berbeda-beda pula.

Secara garis besar dapat dikemukakan ciri-ciri dari diglosia yang merupakan refleksi dari pengertian-pengertian di atas sebagai berikut, Pertama, digunakannya dua variasi dari satu bahasa atau dua bahasa yang hidup berdampingan dalam suatu masyarakat. Ciri ini menunjukkan, bahwa dua variasi atau lebih hidup berdampingan yang digunakan oleh suatu kelompok masyarakat tertentu. Kedua, kedua variasi atau bahasa itu mempunyai peranan sendiri-sendiri di dalam masyarakat pemakainya. Ciri ini menunjukkan bahwa pemakaian variasi atau bahasa ini tidak dapat secara sembarangan dalam penggunaannya. Dengan kata lain, penggunaan variasi bahasa ini sangat tergantung pada tempat, lawan bicara, situasi, dan keperluannya. Bahasa yang satu digunakan dalam situasi yang bersifat resmi, sedang yang lainnya biasa digunakan dalam situasi yang tak resmi.

Keempat, Hubungan Sinergis Bilingualisme dan Diglosia. Fishman dalam (Suwito, 1983:58 dan Alwasilah, 1989:144) menyebutkan 
bahwa terdapat empat jenis masyarakat tutur yang menunjukkan hubungan sinergis yaitu: Pertama, Masyarakat yang diglosik dan dwibahasawan (diglossia and Bilingualism), masyarakat tutur yang diglosik dan dwibahasawan merupakan msyarakat tutur yang secara keseluruhan menggunakan dua bahasa sebagai alat berkomuniksi, tetapi di dalam masyarakat itu kedua bahasa tersebut dipergunakan sesuai dengan fungsinya masing-masing. Kedua, masyarakat yang diglosik tetapi tidak dwibahasawan (Diglossia Without Bilingualism) adalah masyarakat tutur yang ditandai dengan adanya dua atau lebih masyarakat tutur yang secara politis, ekonomis, dan religius dipersatukan kedalam satu kesatuan namun perbedaan sosiokultural tetapi memisahkannya. Ketiga, masyarakat yang dwibahasawan tetapi tidak diglosik (Bilingualism without Diglossia), keadaan masyarakat tutur yang dwibahasawan dan tidak diglosik terdapat dalam masyarakat yang menggunakan dua bahasa sebagai alat berkomunikasi. Kedua bahasa tersebut tidak menunjukkan adanya pembagian fungsi dan penggunaannya. Hal ini menunjukkan bahwa kedua bahasa tersebut dapat dipakai untuk keperluan apapun, kepada siapapun, dimanapun, serta dalam situasi bagaimanapun. Keempat, masyarakat yang tidak diglosik dan tidak dwibahasawan (Neither Diglossia nor Bilingualism). Keadaan masyarakat yang demikian ini agak langka dan tidak begitu jelas.

Kelima, Peristiwa Kontak Bahasa. Bahasa yang bertemu dengan bahasa lain pasti terjadi kontak. Mac Key (1968:554) menjelaskan bahwa kontak bahasa adalah pengaruh bahasa yang satu dengan bahasa yang lain secara langsung ataupun secara tidak langsung. Dalam kegiatan sehari-hari kita tidak biasa lepas dari proses komunikasi dengan bahasa, maka tidak jarang timbul peristiwa-peristiwa bahasa seperti interferensi. Kontak bahasa yang menimbulkan interferensi sering dianggap peristiwa negatif, karena masuknya unsur-unsur bahasa pertama ke dalam bahasa kedua atau sebaliknya menyimpang dari kaidah bahasa masing-masing.

Proses terjadinya kontak bahasa dalam suatu interaksi linguistik harus mengetahui hubungan peran yang ada di antara peserta 
percakapan. Hal penting yang perlu diperhatikan adalah bahwa kontak bahasa itu merupakan hasil bersama (joint production). Salah satu implikasinya para pemakai bahasa harus saling memperhatikan pembicaraan dalam kontak tersebut (Ibrahim, 1993:171). Pengetahuan tentang hal itu diperoleh bersamaan atu sekaligus dengan pengetahuan dasar bahasa pertama atau bahasa ibu. Pengetahuan tersebut juga merupakan bagian dari norma-norma serta perilaku kemasyarakatan yang merupakan dasar bagi berdirinya suatu masyarakat bahasa. Eksistensi suatu masyarakat bahasa banyak bergantung pada normanorma serta perilaku sosial.

Peristiwa kontak bahasa terjadi dalam situasi konteks sosial, yaitu situasi di mana seseorang belajar bahasa kedua di dalam masyarakatnya. Dalam situasi seperti itu dapat dibedakan antara situasi belajar bahasa, proses pemerolehan bahasa, dan orang yang belajar bahasa (Suwito, 1983:39). Dalam interaksi sosial terjadi kontak bahasa saling pengaruh dan mempengaruhi. Orang yang lebih aktif dalam berbicara, akan banyak mendominasi dalam proses interaksi tersebut. Tak heran apabila suatu bahasa sering dipakai dalam berkomunikasi, maka kemungkinan besar bahasa tersebut akan mengalami perkembangan dalam pemakaiannya.

\section{Peran Sosiolinguistik terhadap kajian Bahasa Sastra}

Sosiolinguistik merupakan studi tentang sifat-sifat bahasa, variasi bahasa, fungsi bahasa, dan pemakaian bahasa dalam jalinan interaksi serta fungsi bahasa dalam masyarakat. Sumbangan yang dapat diberikan sosiolinguistik dalam kajian bahasa sastra antara lain: Pertama, Sosiolinguistik dapat memberikan gambaran keadaan sosial suatu masyarakat berkaitan dengan bahasanya. Kedua, Sosiolinguistik dapat digunakan untuk mendeskripsikan adanya variasi-variasi yang ada dalam masyarakat tertentu. Ketiga, sosiolinguistik dapat membantu untuk menentukan atau memilih variasi bahasa mana yang akan kita gunakan yang sesuai dengan situasi dan fungsinya.

Sosiolinguistik merupakan cabang linguistik yang bertujuan 
menemukan prinsip- prinsip yang mendasar beberapa bahasa dengan jalan lebih komprehensif dan dengan melibatkan perhitungan pengaruh berbagai konteks sosial (Poedjosoedarmo, 1986:4). Penelitian dengan pendekatan sosiolinguistik terhadap karya sastra pada akhirnya harus dapat menjelaskan adanya beberapa variasi bahasa, variasi tuturan seperti dialek, gaya bahasa, ragam bahasa, tingkat tutur, membagi idiom serta mengungkapkan relasi yang meliputi arti bahasa yang lebih mendalam. Studi tentang bahasa ada yang dilakukan secara linguistik semata, namun ada pula yang disertai faktor non-linguistik. Secara linguistik dimaksudkan untuk merumuskan kaidah-kaidah bahasa, menentukan pola-pola struktur bahasa, memberikan deskripsi tentang bahasa serta berusaha menganalisis bahasa sastra berdasarkan hakikat bahasa itu sendiri sebagai objek yang mandiri.

Di samping itu, Seorang pengarang sastra (sastrawan) pada umumnya adalah seorang dwibahasawan atau multibahasawan yang hidup dalam masyarakat diglosik, sehingga dapat mengenal atau menguasai lebih dari satu bahasa, dan bahkan sebagai seorang sastrawan pun tidak lepas dari penggunaan bahasa lain di samping bahasa yang digunakan dalam tuturan kesehariannya. Dalam membawakan karyanya seorang sastrawan sering memasukkan unsur bahasa daerahnya, agar karangannya lebih menarik bagi publik atau pembaca.

\section{Fungsi Sosiolinguistik terhadap kajian Bahasa Sastra}

Bahasa bagi seorang sastrawan atau penyair merupakan sebuah media untuk menuangkan ide-ide sekaligus sebagai sarana untuk menyampaikan pesan-pesan tertentu pada masyarakat. Ide-ide tersebut bersumber dari dari intuisi, imaji, dan pengalaman diri peribadi seorang sastrawan dalan masyarakatnya. Oleh karena itu karya sastra merupakan suatu karya tulis yang intuitif, karya tulis yang imajinatif, dan sekaligus sebagai karya seni, sebab diciptakan dengan karya kreasi sastrawan atau penyair yang merupakan anggota dari kelompok masyarakat yang berjiwa seni. Menurut Siswo Sugiarto (1996: 20) bahasa 
sastra dapat dimanfatkan sedemikian rupa, sehingga dalam fungsinya bahasa sastra dapat mendukung kemampuan daya cipta sastrawan itu sendiri. Bahkan bahasa tidak saja sebagai media penciptaan, tetapi sekaligus merupakan bahasa yang bernilai seni.

Hubungan bahasa dan sastra yang khas adalah seperti yang terlihat dalam drama, baik di atas pentas maupun sebagai teks untuk dibaca (novel) (Anwar, 1990: 55). Di sini, bahasa dipakai tidak dalam situasi wajar pemakaian bahasa. Yaitu untuk berkomunikasi pada umumnya, untuk melakukan fungsi interaksi sosial. B. Rahmanto (1999:74) mensinyalir bahwa unsur-unsur kebahasaan dalam karya sastra merupakan sumber bahasa yang cukup luas untuk dikaji dan dipelajari. Unsur-unsur yang perlu dikaji dan dipelajari antara lain meliputi dialek, register, idiolek personal, sosiolek dan sebagainya. Begitu juga karya seni dalam bentuk sastra fiksi (novel, puisi, dan drama) menggunakan bahasa untuk menciptakan sebuah dunia yang berbeda yang dapat disaksikan orang lain secara nyata melalui tuturan serta adegan-adegan tokoh yang "dihidupkan" sang sutradara.

Bahasa sastra yang digunakan dalam karya sastra mempunyai ciri khas tersendiri yaitu lebih mengedepankan aspek estetis yang senantiasa bernuansa hiburan dan sekaligus sebagai media penyampai pesan-pesan pengarang melewati tokoh-tokoh yang "dihidupkan" di dalamnya. Novel sebagai salah satu bentuk karya sastra disajikan oleh pengarang dengan karakteristik bahasa yang berbeda. Perbedaan itu tergantung dari cara pengarang itu sendiri di dalam meyajikan karyanya. Di dalam karya fiksi (novel) tersebut pengarang melewati peranan tokoh-tokohnya menyajikan tuturan yang sesuai dengan kapasitas dan status sosial tokoh-tokoh tersebut, sehingga dalam tuturan tokoh-tokoh tersebut banyak dijumpai adanya peristiwaperistiwa kebahasaan sesuai dengan perbedaan latar belakang sosiosituasional dan sosio-kultural bahasanya.

Menurut Cumming dan Simons (1986:vii) karya sastra mempunyai status khusus sebagai seni verbal, di mana bahasa sebagai inti semiotika kemanusiaan yang merupakan aktivitas yang bermakna 
dalam komunitasnya. Dengan demikian bahasa sastra atau bahasa cipta sastra dapat dikaji secara makrolinguistik dan secara mikrilinguistik.

Adapun kajian bahasa dari segi makrolinguistik yang bersifat interdisipliner berarti kajian bahasa yang menggunakan beberapa bidang kajian. Kajian bahasa sastra secara sosiolinguistik berarti kajiannya menggunakan teori sosiologi dan linguistik. Sosiolinguistik (sosiologi bahasa) merupakan salah satu "pisau" analisis kebahasaan untuk mengkaji bahasa sastra dengan memperhitungkan hubungan antara bahasa dan masyarakat, khususnya masyarakat penutur bahasa itu. Jadi jelas dalam hal ini, kajian sosiolinguistik mempertimbangkan hubungan antara linguistik untuk segi kebahasaan dan sosiologi untuk segi kemasyarakatannya serta karya sastra (seni verbal) sebagai obyek kajiannya.

Dengan demikian, kehadiran sosiolinguistik terhadap kajian bahasa sastra tidak hanya sekedar kritik, tetapi juga memberikan kontribusi dengan berusaha menguraikan peristiwa-peristiwa tuturan bahasa berdasarkan faktor sosio-situasional yang dilakukan oleh para tokoh cerita dengan latar belakang sosialnya masing-masing berdasarkan fungsi dan karakternya.

Pengkajian terhadap bahasa sastra juga tidak dapat dilepaskan dari pengertian bahasa dalam karya sastra (Teeuw, 1983: 22). Bagaimana pun rumusan dan pengertian para ahli tentang sastra, bahasa tetap merupakan medium bagi penciptaan karya sastra yang tidak dapat diabaikan (Widdowson, 1978: 203). Bahasa dalam karya dan cipta sastra dapat disejajarkan dengan garis dan bidang bagi seni lukis, gerak dan irama pada seni tari, nada dan irama pada seni musik, dan sebagainya (Subroto, 1976: 13). Oleh karena itu karya sastra memiliki status khusus sebagai seni verbal, dalam hal ini bahasa sebagai inti semiotika kemanusiaan merupakan aktivitas yang bermakna dalam komunitasnya (Cummings, 1986: vii). Penelitian yang mengkaji bahasa dalam karya sastra pada dasarnya sedang meletakkan karya sastra sebagai proses komunikasi yang dilakukan oleh pengarang kepada pembaca lewat lambang-lambang bahasa. 
Kajian yang tepat untuk meneliti peristiwa kebahasaan dalam konteks kedwibahasaan pengarang dalam karya sastra tersebut adalah kajian sosiologi bahasa (sosiolinguistik). Sosiolinguistik mengkaji bahasa dengan memperhitungkan hubungan antara bahasa dengan masyarakat termasuk pengarang, khususnya masyarakat penutur bahasa itu. Jadi jelas sosiologi bahasa sastra mempertimbangkan keterkaitan dua hal, yakni linguistik untuk segi kebahasaan (media pemciptaan sastra) dan sosiologi untuk segi kemasyarakatannya. Dan kenyataan memang menunjukkan bahwa pada umumnya, penelitian bahasa dalam kerangka sosiologi bahasa mendasarkan kajian bahasa yang merupakan mediasi dari karya seni dalam hubungannya dengan masyarakat (pengarang). $\nabla$

\section{DAFTAR PUSTAKA}

Alwasilah, Chaedar. 1989. Sosiologi Bahasa. Bandung: Angkasa.

Anwar, Khaidir. 1990. Fungsi dan Peranan Bahasa: Sebuah Pengantar. Yogyakarta: Gajah Mada University Press

Bloomfield, Leonard. 1976. Language. New York: Holt, Rine hart and 
Winston.

Chaer, Abdul dan Leonie Agustina. 1995. Sosiolinguistik. Jakarta: Rineka Cipta.

Chakledar, Snehamoy. 1990. Sociolinguistics, A Guide to Language Problem in India. New delhi India: Mittal Publications.

Cummings, and R. Simmons. 1986. The Language of Leterature. England: Peogeon Press.

Dulay, dkk. 1982. Language Two. New York: Oxford University.

Ervin, S.M. and Osgood, C.E. 1965. Second Language Learning and Bilingualism. Bloomington: Indiana University Press.

Fishman, Joshua. 1975. Sociolinguistics, a Brief Introduction. Massachusitts: Publiser Rowley.

Hudson, R.A. 1980. Sociolinguistics, Cambridge: University Press.

Ibrahim, Abdul Syukur. 1995. Sosiolinguistik. Surabaya: Usaha Nasional.

Kridalaksana, Harimurti. 1993. Kamus Linguistik. Jakarta: Gramedia Pustaka Utama.

Nababan, P.W.J. 1993. Sosiolinguistik: Suatu Pengantar. Jakarta: Gramedia Pustaka Utama.

Richards, Jack C. 1974. Error Analisys. London: Longman Group Limited. .1989. Perkembangan Sosiolinguistik. Yogyakarta: Balai Penelitian Bahasa.

Robins, R.H. 1992. Linguistik Umum: Sebuah Pengantar. Yogyakarta: Kanisius.

Subroto, Edi. 1976. "Hakekat Bahasa dan Realisasinya dalam Puisi," dalam Majalah Bahasa dan Sastra. Jakarta: Pusat Pembinaan dan Pengembangan Bahasa.

Sugiarto, Siswo. 1996. "Bahasa dan Sastra” dalam Majalah FILLITRA. No. 05 Edisi Juni-Oktober.

Suwito. 1983. Pengantar Awal Sosiolinguistik, Teori dan Problema. Surakarta: Henary Offset.

Teeuw, A. 1983. Sastera dan Ilmu Sastera. Jakarta: Pustaka Jaya. 
Wahab, Abdul. 1991. Isu Linguistik Pengajaran Bahasa dan Sastra. Surabaya: Airlangga University Press.

Weinreich, Uriel. 1974. Languages in Contact. Paris: The Hague. 